\title{
Penghargaan Hak Berpendapat Anak di Pengadilan: Studi Kasus di Pengadilan Negeri Semarang
}

\author{
Rika Saraswati, ${ }^{1}$ \\ V. Hadiyono ${ }^{2}$ \\ 1,2Universitas Katolik Soegijapranata \\ Semarang \\ email: ${ }^{1}$ rikasaraswati@unika.ac.id; \\ ${ }^{2}$ lopid@unika.ac.id
}

\begin{abstract}
The right of children to be heard are guaranteed by the Child Protection Act in Indonesia. This is very principle as the main factor for judges to make decisions regarding disputes over child custody. The purpose of this study is to examine the implementation of laws in Indonesia that regulate children's rights to be heard in court. Data was taken by conducting documentary research and field research by collecting several decisions from the District Court of Semarang and interviewing the judges who handled this matter. This research shows that children are rarely asked for their opinions in the courtroom; Their opinions are only considered information, not as witness statements. As a result, their opinions and expectations have no effect on court decisions. The study also shows that the law in Indonesia has regulated the obligation of judges to listen to the opinions of children in court, but judges never consider it.
\end{abstract}

Keywords: the bestinterests of the child; the right of children to be heard; court

Abstrak: Hak anak untuk didengar dijamin oleh UndangUndang Perlindungan Anak di Indonesia. Hal ini sangat prinsip sebagai faktor utama bagi hakim untuk membuat keputusan terkait sengketa hak asuh anak. Tujuan penelitian ini adalah untuk menguji implementasi undang-undang di Indonesia yang mengatur tentang hak-hak anak untuk didengar di pengadilan. Data diambil dengan melakukan penelitian dokumenter dan penelitian lapangan dengan mengumpulkan beberapa keputusan Pengadilan Negeri Semarang dan mewawancarai para hakim yang menangani masalah ini. Penelitian ini menunjukkan bahwa anak-anak jarang diminta pendapatnya dalam ruang sidang;. Pendapat mereka Cuma dianggap sebagai informasi, bukan sebagai pernyataan para saksi. Sebagai akibatnya, pendapat dan harapan mereka tidak berpengaruh terhadap putusan pengadilan. Studi ini juga menunjukkan bahwa undangundang di Indonesia telah mengatur kewajiban hakim untuk mendengarkan pendapat anak-anak di pengadilan, namun hakim tidak pernah mempertimbangkan hal itu.

Kata Kunci: kepentingan terbaikbagi anak; hakanakuntuk didengar pendapatnya; pengadilan 


\section{A. Pendahuluan}

Prinsip dasar kepentingan yang terbaik bagi anak menurut penjelasan Pasal 2 UU Perlindungan Anak Nomor 23 Tahun 2002 (UUPA) diartikan sebagai "semua tindakan yang menyangkut anak yang dilakukan oleh pemerintah, masyarakat, badan legislatif, dan badan yudikatif, maka kepentingan yang terbaik bagi anak harus menjadi pertimbangan utama."

Berdasarkan ketentuan tersebut maka hakim sebagai lembaga yudikatif yang menjalankan peradilan wajib menerapkan asas ini, khususnya dalam proses persidangan dan membuat putusan yang perkaranya melibatkan atau berpengaruh terhadap kehidupan anak. Selain asas kepentingan terbaik anak, terdapat asas penghargaan terhadap hak berpendapat anak yang memberikan mandat bahwa anak-anak berhak menyatakan pendapatnya di manapun dan tentang apapun dan orang dewasa memiliki kewajiban untuk mendengarkan, mempertimbangkan dan memenuhi keinginan anak-anak tersebut apabila hak berpendapat tersebut berkaitan erat dengan kepentingan yang terbaik bagi kehidupan atau masa depan anak tersebut (Penjelasan Pasal 2 UUPA).

Kedua asas ini saling melengkapi dan bersifat wajib untuk diterapkan, termasuk ketika menyangkut hak-hak anak di pengadilan. Hak berpendapat anak menjadi hal yang sangat penting untuk didengarkan oleh orang dewasa atau pemerintah ketika orangtua bercerai dan berselisih di pengadilan untuk menentukan hak pemeliharaan anak di kemudian hari.

Persoalan 'kepentingan' bagi anak diatur oleh Undang-Undang Nomor 1 Tahun 1974 tentang Perkawinan (UUP), akan tetapi UUP tidak mengatur mengenai apa yang dimaksud dengan kepentingan anak. Penjabaran kepentingan' anak diatur di dalam Undang-Undang Nomor 23 Tahun 2002 tentang Perlindungan Anak (UUPA) yang oleh UUPA dinyatakan sebagai suatu prinsip atau asas kepentingan terbaik anak sebagaimana telah disebutkan dalam alinea sebelumnya.

Ketentuan mengenai hak berpendapat anak juga tidak terdapat di dalam UUP, tetapi diatur di dalam Pasal 10 Undang-Undang Nomor 23 Tahun 2002 tentang Perlindungan Anak (UUPA) yang menyatakan bahwa "Setiap anak berhak menyatakan dan didengar pendapatnya, menerima, mencari, dan memberikan informasi sesuai dengan tingkat kecerdasan dan usianya demi pengembangan dirinya sesuai dengan nilai-nilai kesusilaan dan kepatutan". 
Berdasarkan UUPA maka batas usia anak adalah sampai dengan delapan belas (18) tahun. Hal ini dapat dimaknai bahwa hak anak untuk didengar pendapatnya dapat dilakukan di usia berapapun sampai si anak berumur 18 tahun. Ketentuan peraturan perundang-undangan yang mengatur secara jelas usia anak yang dapat didengarkan pendapatnya adalah Kompilasi Hukum Islam (KHI) yang berlaku bagi mereka yang beragama Islam dan mengajukan gugatan hak pemeliharaan anak ke Peradilan Agama. ${ }^{1}$

Berdasarkan Pasal 9 (1) dan (2) Konvensi Hak Anak Negara-negara Pihak, termasuk Indonesia yang sudah meratifikasi Konvensi Hak Anak melalui Peraturan Pemerintah Nomor 36 Tahun 1990 harus menjamin bahwa setiap anak mempunyai kesempatan untuk didengar pendapatnya ketika berhadapan dengan proses hukumm termasuk ketika seorang anak akan dipisahkan dari orangtuanya jika hal tersebut diperlukan untuk kepentingan yang terbaik bagi anak sesuai dengan peraturan perundang-undangan dan prosedur yang berlaku. Penetapan demikian diperlukan dalam kasus khusus, yakni kedua orangtuanya hidup terpisah, dan keputusan harus dibuat untuk menetapkan tempat tinggal anak tersebut. Dalam setiap proses hukum tersebut maka semua pihak yang berkepentingan harus diberi kesempatan untuk turut serta dalam proses tersebut, dan diberi kesempatan untuk mengemukakan pandangan mereka. Berdasarkan pasal tersebut maka jelas sekali bahwa anak memiliki hak yang sama dengan orang dewasa (orangtuanya) untuk didengar pendapatnya oleh pengadilan.

Asas penghargaan terhadap hak berpendapat anak dalam Konvensi Hak Anak tersebut merupakan ketentuan yang sangat progresif dalam mengatur dan menjamin pemenuhan hak-hak anak. Akan tetapi hal tersebut ternyata menimbulkan ketidakpastian bagi orangtua dan professional tentang bagaimana, kapan atau perlukah melibatkan anak-anak dalam proses pengambilan keputusan hukum di bidang keluarga (misalnya dalam proses perceraian dan penetapan hak asuh anak). Pandangan demikian muncul karena dominasi pandangan orang dewasa yang memandang rendah terhadap kedewasaan anak dan kompetensinya untuk memberikan kontribusi secara efektif terhadap

'Pasal 105 KHI mengatur bahwa dalam hal terjadinya perceraian : a) pemeliharaan anak yang belum mumayyiz atau belum berumur 12 tahun adalah hak ibunya; b) pemeliharaan anak yang sudah mumayyiz diserahkan kepada anak untuk memilih di antara ayah atau ibunya sebegai pemegang hak pemeliharaannya; c) biaya pemeliharaan ditanggung oleh ayahnya. 
keputusan di dalam keluarga dan dalam Pengadilan keluarga. ${ }^{2}$ Berbagai hasil penelitian justru menunjukkan bahwa pandangan yang memandang bahwa kesaksian seorang anak lemah atau tidak berharga demikian patut ditinggalkan karena tidak sesuai dengan konsep dan pandangan terbaru yang melihat anakanak sebagai warga negara, agen dan sosial actor yang memiliki hak-haknya seperti halnya manusia dewasa. Anak-anak bukanlah pengikut orangtuanya. ${ }^{3}$ Anak-anak yang orangtuanya bercerai dan menjadi obyek penelitian justru menunjukkan bahwa mereka mampu menyampaikan pandangan dan gagasannya dengan baik, jelas dan mudah dipahami terhadap permasalahan yang di-

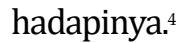

Menurut Fitzgerald, ketika hukum keluarga telah memulai untuk lebih bersiap merengkuh anak-anak sebagai agen, warga negara, dan aktor sosial maka para pembuat kebijakan dan keputusan harus bersiap-siap menghadapi munculnya 'ruang-ruang' baru sebagai akibat dari pengakuan atas perspektif anak-anak tersebut. ${ }^{5} \mathrm{Hal}$ ini semestinya tidak menjadi halangan bagi professional untuk bekerja dengan anak-anak karena yang dibutuhkan oleh para professional adalah keahlian dan ketrampilan dalam berkomunikasi dengan anak-anak ${ }^{6}$ Hasil penelitian terhadap anak-anak berusia 7-12 tahun tentang pengetahuan dan pertimbangan anak-anak tentang permasalahan hukum yang berkaitan dengan kehidupan mereka secara pribadi telah menunjukkan meningkatnya pemahaman mereka tentang konsep-konsep hukum.7 pengetahuan dan pemahaman anak-anak tentang hukum, proses hukum, dan istilahistilah hukum muncul secara bertahap dan semua itu bergantung pada kompleksitas konsep-konsep hukum yang mereka pelajari. Ketidaktahuan dan salah paham tentang sistem hukum merupakan hal yang wajar bagi anak-anak

${ }^{2}$ Nicola Taylor, "What Do We Know about Involving Children and Young People in Family Law Decision Making? A Research Update," Australian Journal of Family Law 20 (2006): 154.

3 Jennifer Flowerdew dan Bren Neale, "Trying to Stay Apace: Children with Multiple Challenges in Their Post-Divvorce Family Lives," Childhood Journal 10, no. 2 (2003): 148.

${ }^{4}$ Flowerdew dan Neale.

${ }^{5}$ Robyn Fitzgerald, "How Are Children Heard in Family Law Proceeding in Australia?," Southern Cross University Law Review 6 (2002): 177-203.

6Taylor, "What Do We Know about Involving Children," 169.

${ }^{7}$ Michele Peterson Badali, Rona Abramovitch, dan Juliane Duda, "Young Children's Legal Knowledge and Reasoning Ability," Canadian Journal of Criminology39, no. 2 (1997): 145-170. 
mengingat banyak orang dewasa yang tidak memiliki pengetahuan dan pemahaman yang baik tentang pengetahuan dan sistem hukum. ${ }^{8}$

Hasil penelitian terhadap pengalaman anak-anak yang orangtuanya bercerai juga menunjukkan bahwa membiarkan mereka di dalam 'kegelapan' karena tidak pernah didengar pendapatnya, tanpa interaksi dan komunikasi yang baik yang dilakukan oleh orang tua/dewasa terhadap anak-anak ternyata telah menyumbangkan kebingungan dan rasa sakit sehingga mereka merasakan masa transisi (perpisahan orangtuanya) menjadi semakin sulit. ${ }^{9}$ Anakanak yang tidak mendapat informasi yang layak tentang perpisahan tampak lebih mudah mengalami gejala-gejala seperti kekuatiran, depresi, perilaku salah, distress dan menyalahkan diri sendiri atas perpisahan orangtuanya. Mereka dapat mengatasinya dengan baik apabila mendapatkan informasi, turut dilibatkan dan mendapatkan bantuan untuk memahami perubahan yang sedang dan akan terjadi, dan turut berpartisipasi secara aktif di dalam proses tersebut. Dengan demikian melibatkan anak sejak awal di dalam proses pembuatan keputusan memiliki akibat yang positip terhadap anak, tidak hanya terhadap perkembangan identitas individunya, pertmbangan moral, kompetensi tetapi juga memberikan kepuasan terhadap apapun hasil yang nantinya dicapai. $^{10}$

Meskipun hasil penelitian tersebut menyatakan hal-hal yang berakibat positip terhadap keterlibatan anak-anak sejak awal dalam proses pengambilan keputusan atas perpisahan orangtuanya, dalam kenyataan masih banyak anakanak yang tidak mendapatkan konsultasi tentang hal-hal yang berkaitan dengan kesepakatan perpisahan dan pasca perpisahan. ${ }^{11}$ Hal ini disebabkan

\footnotetext{
${ }^{8}$ Catherine Maunsel, "What Do They Know about the Legal System? Intreviews with Irish Children," Dalam Researching Children's Experiences: Qualitative Approaches, ed. Diane Hogan dan Robbie Gilligan (Dublin: The Children's Research Centre, 1998), 35-49; Taylor, "What Do We Know about Involving Children."

9Carol Smart, "Introduction: New Perspectives on Childhood and Divorce," Childhood 10, no. 2 (2003): 123-29, https://doi.org/10.1177/0907568203010002001.

${ }^{10}$ Maunsel, "What Do They Know about the Legal System? Intreviews with Irish Children”; Taylor, "What Do We Know about Involving Children and Young People in Family Law Decision Making? A Research Update."

${ }^{11}$ Maunsel, "What Do They Know about the Legal System? Intreviews with Irish Children”; Taylor, "What Do We Know about Involving Children and Young People in Family Law Decision Making? A Research Update."
} 
karena keengganan orang dewasa dan para professional untuk melibatkan anak-anak berdasarkan pertimbangan bahwa proses di pengadilan 'melelahkan', membuat stress, dan 'merusak'. ${ }^{12}$ Selain itu sistem hukum sendiri tampaknya juga tidak nyaman dengan melibatkan anak dalam proses pengadilan sehingga pandangan-pandangan anak-anak ini hanya diinterprestasikan dan disaring melalui berbagai professional yang berbeda (kuasa hukum anak atau pendamping anak, pekerja sosial dan hakim) berdasarkan sudut pandang mereka, sehingga pandangan dan pendapat anak-anak itu sendiri secara langsung jarang sekali digunakan untuk menentukan keputusan dalam proses persidangan hukum keluarga..$^{13}$

Penelitian ini merupakan penelitian kualitatif yang dilakukan di Pengadilan Negeri Semarang mengenai hak berpendapat anak dalam Putusan Pengadilan tentang Hak Pemeliharaan dan Mendidik Anak dikarenakan perceraian orangtuanya. Penelitian kualitatif dilakukan dengan melakukan wawancara kepada seorang hakim dan meneliti sejumlah 5 putusan pada kurun waktu 2014-2016. Terbatasnya jumlah hakim yang diwawancarai karena sudah ditentukan oleh pihak Pengadilan Negeri Semarang. Jumlah putusan yang diperoleh juga terbatas karena sebagian besar kasus yang terdapat di Pengadilan Negeri Semarang mengenai perceraian tanpa disertai dengan permohonan penetapan hak asuh anak (hak pemeliharaan dan mendidik anak). Analisis terhadap putusan ini bersifat deskriptif kualitatif.

\section{B. Beberapa Putusan Pengadilan Negeri Semarang terkait Kasus Perceraian}

Berdasarkan penelitian atas lima putusan Pengadilan Negeri Semarang, diperoleh hasil sebagai berikut:

\section{Putusan Nomor: 293/Pdt.G/2014/PN.Smg}

Kasus ini dimulai ketika penggugat (dalam hal ini adalah istri) yang sudah menikah dengan tergugat (dalam hal ini suami) selama sebelas tahun meng-

\footnotetext{
${ }^{12}$ Gillian Douglas dan Mervyn Murch, "Taking Account of Children's Need in Divorce: A Study of Family Solicitors 's Responses to New Policy and Practice Initiatives," Child and Family Law Quarterly 14, no. 1 (2002): 57-75.

${ }^{13}$ Fitzgerald, "How Are Children Heard in Family Law Proceeding in Australia?"
} 
ajukan gugatan cerai dengan alasan; tergugat memiliki wanita idaman lain di tahun kedua perkawinan dan tahun ke Sembilan usia perkawinan. Selain itu, tergugat tidak pernah memberi nafkah kepada Penggugat. Tergugat memiliki kebiasaan buruk dalam masalah keuangan, misalnya suka meminjam uang kepada banyak teman dan tidak pernah mengembalikannya. Kebiasaan buruk ini yang menyebabkan ia berpindah tempat kerja hingga dua kali. Tergugat telah pergi meninggalkan penggugat dan kedua anaknya yang berusia 10 (sepuluh) tahun dan 4 (empat) tahun. Tergugat meninggalkan penggugat dan anak-anaknya sejak tahun 2012. Upaya penggugat untuk menghubungi tergugat tidak mendapat respon yang baik sehingga sampai gugatan ini diajukan tergugat tidak pernah kembali. Meskipun berada di Semarang, penggugat dan tergugat telah berpisah dan tinggal di tempat yang berbeda; Penggugat saat ini tinggal bersama dengan orangtuanya, sedangkan tergugat tinggal di rumah saudaranya. Hakim memutuskan anak-anak hasil perkawinan penggugat dan tergugat di bawah asuhan, bimbingan dan pemeliharaan penggugat selaku ibunya berdasarkan pertimbangan kedua anak tersebut belum berusia 18 tahun dan selama ini tinggal bersama ibunya. Putusan ini tidak mengurangi kewajiban tergugat sebagai ayahnya untuk memberikan biaya pemeliharaan dan pendidikan bagi anak-anaknya tersebut.

Di dalam putusan tersebut tidak terdapat pertimbangan hukum yang menyatakan bahwa anak-anak telah didengarkan pendapatnya, baik di dalam persidangan ataupun di luar persidangan. Hakim hanya mempertimbangkan usia yang masih belum cukup umur di bawah 18 tahun dan faktor kedekatan anak dengan salah satu orangtuanya digunakan untuk menentukan salah satu dari pihak yang berperkara yang berhak memelihara anaknya pemeliharaan anaknya.

\section{Putusan Nomor: 285/Pdt.G/2014/PN.Smg}

Penggugat (dalam hal ini suami) dan tergugat (dalam hal ini istri) telah menikah selama 15 tahun. Gugatan perceraian diajukan karena penggugat dan tergugat sering cekcok dan setiap kali terjadi percekcokan yang hebat tergugat selalu ingin bercerai. Tergugat sering marah-marah kepada suaminya tanpa sebab. Pada tahun 2002, 2005 dan 2007 percekcokan terjadi di antara mereka berdua, dan tergugat pernah menggugat cerai suaminya pada tahun 2014. 
Akan tetapi perceraian tidak terjadi karena terjadi perdamaian. Setelah adanya kesepakatan perdamaian, kehidupan perkawinan mereka tidak juga membaik karena percekcokan masih terus terjadi. Hal inilah yang kemudian mendorong penggugat untuk menggugat cerai istrinya karena penggugat merasa tidak bisa mempertahankan perkawinannya. Penggugat juga mengajukan permohonan penetapan hak memelihara dan mendidik anak terhadap ketiga anaknya yang berusia 14 tahun, 12 tahun dan 9 tahun.

Hakim Pengadilan Negeri memutuskan untuk mengabulkan gugatan perceraian penggugat karena berdasarkan fakta bahwa penggugat dan tergugat telah pisah rumah selama satu tahun Sembilan bulan. Permohonan hak memelihara dan mendidik anak diserahkan kepada penggugat oleh hakim setelah mendengarkan keterangan penggugat dan saksi-saksi yang diajukan oleh penggugat. Majelis hakim berpendapat bahwa hubungan ketiga anak dengan penggugat lebih dekat dibandingkan dengan tergugat, bahkan hingga gugatan perceraian diajukan ketiga anak tinggal bersama dengan penggugat maka majelis hakim menganggap sudah cukup alasan menurut hukum untuk menyerahkan hak asuh anak kepada penggugat dengan tetap memberi kesempatan kepada tergugat sebagai ibu kandungnya untuk bertemu dengan anak kandungnya.

Hakim yang diwawancarai menyatakan bahwa anak selalu diminta pendapatnya dalam setiap kasus mengenai hak asuh anak. ${ }^{14}$ Akan tetapi, dalam putusan ini tidak terdapat satu bagian pun yang menunjukkan pendapat anak telah didengarkan atau catatan mengenai hasil wawancara hakim dengan anak terkait dengan haknya ingin tinggal dengan siapa dan alasannya ingin tinggal.

\section{Putusan Nomor:38/Pdt.G/2015/PN.Smg}

Penggugat (dalam hal ini istri) dan tergugat (dalam hal ini suami) telah menikah selama sepuluh tahun dan memiliki seorang anak berusia 9 tahun. Penggugat mengajukan dalil bahwa percekcokan dan perselisihan beberapa kali terjadi. Setiap kali berselisih pendapat tergugat sering memukul penggugat dan mengucapkan kata-kata yang bersifat mengancam dan kata 'cerai'. Menurut penggugat, kekerasan selalu menjadi cara bagi tergugat untuk menye-

\footnotetext{
14 Wawancara dengan Hakim Enny Indriyani, SH, Selasa 7 Juni 2016, jam 10.30-12.00.
} 
lesaikan masalah. Kekerasan dilakukan tidak hanya terhadap penggugat tetapi juga kepada anaknya. Kekerasan terakhir yang dilakukan oleh tergugat menyebabkan penggugat tidak masuk kerja selama dua hari; Penggugat tidak melaporkan ke polisi karena mempertimbangkan anaknya. Penggugat juga menyatakan bahwa tergugat tidak pernah memberi nafkah kepada penggugat dan anaknya.

Dalam kaitannya dengan hak pemeliharaan dan mendidik anak, penggugat memohon kepada majelis hakim untuk menetapkan hak pemeliharaan dan mendidik anak kepada dirinya sebagai ibu kandungnya. Tergugat menyampaikan alasannya karena selama satu tahun berpisah dengan penggugat, anak tinggal bersama dengan tergugat. Tergugat yang merawat anak baik dalam hal sekolah dan belajar, maupun pemenuhan keperluan sehari-hari, bahkan perawatan ketika sakit. Tergugat mengatakan bahwa ketika si anak sakit, penggugat sebagai ibu kandungnya tidak pernah menengok apalagi ikut merawat. Selama ini sang anak tinggal berdua bersama tergugat.

Majelis hakim mengabulkan permohonan penggugat untuk bercerai karena percekcokan dan perselisihan berdasarkan keterangan saksi-saksi, termasuk juga bekas pemukulan di wajah penggugat yang dilakukan oleh tergugat. Dengan demikian, menurut majelis hakim perkawinan yang diwarnai dengan perselisihan dan kekerasan sudah tidak sesuai dengan tujuan perkawinan untuk membentuk keluarga (rumah tangga) yang bahagia dan kekal berdasarkan KeTuhanan yang Maha Esa. Selain itu perselisihan dan percekcokan yang terjadi telah memenuhi ketentuan Pasal 19 huruf (f) Peraturan Pemerintah Nomor 9 tahun 1975 sebagai salah satu alasan perceraian.

Majelis hakim memutuskan hak asuh anak kepada tergugat sebagai ayah dari anak yang diperebutkan hak pemeliharaan dan mendidik. Pertimbangan yang digunakan majelis hakim dalam membuat putusan tersebut didasarkan pada pertimbangan-pertimbangan sebagai berikut: 1) selama penggugat dan tergugat tidak tinggal bersama selama setahun anak telah tinggal bersama tergugat dan tergugat yang merawat anak tersebut, 2) selama waktu itu penggugat sebagai ibunya tidak pernah menengok, 3) untuk kenyamanan anak dan mempertimbangkan perkembangan jiwa anak di kemudian hari maka hak pemeliharaan dan mendidik anak diberikan kepada tergugat. 


\section{Putusan Nomor: 286/Pdt.G/2015/PN.Smg}

Penggugat (dalam hal ini istri) dan tergugat (suami) telah melangsungkan pernikahan pada tahun 2006. Pernikahan mulai tidak harmonis setelah kelahiran anak pertama karena tergugat sering keluar malam bersama-sama dengan temannya. Terjadi pertengkaran di tahun 2012 ketika penggugat mengetahui bahwa tergugat telah menjalin hubungan dengan wanita idaman lain. Akibat pertengkaran tersebut tergugat pernah tidak pulang tiga bulan dan tidur di tempat tergugat menjalankan usahanya. Tergugat pernah berjanji tidak akan berhubungan lagi dengan wanita idaman tersebut, tetapi di tahun 2015 ternyata tergugat masih menjalin hubungan lagi dengan wanita idaman yang sama dan bahkan telah menikah. Mengetahui hal tersebut, penggugat memutuskan untuk berpisah dengan tergugat dan kembali ke Semarang bersama ketiga anaknya. Penggugat juga memohon agar dirinya ditetapkan sebagai pemegang hak pemeliharaan dan mendidik atas ketiga anaknya.

Majelis hakim mengabulkan permohonan gugatan cerai penggugat setelah mendengarkan keterangan saksi yang menerangkan bahwa antara penggugat dan tergugat sering terjadi pertengkaran yang disebabkan sikap tergugat yang tidak memperhatikan keluarganya dan memiliki wanita idaman lain. Majelis hakim juga mengabulkan permohonan hak pemeliharaan dan mendidik anak yang diajukan oleh penggugat berdasarkan pertimbangan bahwa anak-anak tersebut belum dewasa dan kedekatan hubungan dengan ibunya dan selama ini tinggal bersama ibunya di Semarang maka demi pertumbuhan dan perkembangan anak, serta menjauhkan dari dampak buruk perilaku tergugat yang tidak bertanggungjawab kepada keluarga maka hak asuh diserahkan kepada penggugat sebagai ibunya.

Akan tetapi tidak ada penjelasan mengenai pelaksanaan asas penghargaan terhadap hak berpendapat anak mengingat usia anak-anak penggugat yang masih sangat muda, saat gugatan perceraian diajukan usia anak tertua hingga termuda secara berturut-turut adalah 8, 2 dan 1 tahun. Apabila anak yang berusia 8 tahun tersebut benar-benar dimintai pendapatnya maka hasil pemeriksaan persidangan (terlepas dilaksanakan dalam tempat yang berbeda) terhadap hak berpendapat anak ini seharusnya dituangkan ke dalam putusan ini. 


\section{Putusan Nomor: 19/Pdt.G/2016/PN.Smg}

Penggugat (suami) dan tergugat (istri) telah menikah selama 8 tahun dan memiliki satu anak. Pernikahan mulai tidak harmonis di tahun ke tujuh karena diwarnai percekcokan dan pertengkaran yang disebabkan sikap tergugat yang keras dan banyak tuntutan tanpa mau memahami kesulitan ekonomi yang dialami oleh penggugat. Tergugat sendiri juga jarang pulang ke rumah tanpa alasan yang jelas. Penggugat berusaha untuk meredam percekcokan dengan mengalah dan berkomunikasi, akan tetapi tidak ada tanggapan dan perubahan yang baik dari tergugat. Akhirnya pada tahun 2013 tergugat meninggalkan rumah tanpa seijin penggugat dan tanpa alasan yang jelas, dan hingga gugatan ini diajukan juga tidak pernah pulang dan tidak pernah memberi kabar. Hal tersebut yang mendorong penggugat untuk menggugat cerai. Penggugat juga menohon agar hak pemeliharaan dan mendidik diserahkan kepada penggugat demi perkembangan psikologi kejiwaan anaknya dan karena masih di bawah umur.

Setelah mendengarkan saksi dan mendasarkan pada surat-surat bukti maka majelis hakim berpendapat bahwa memang telah terjadi percekcokan dan pertengkaran terus menerus di antara penggugat dan tergugat, dan upaya untuk mendamaikan juga tidak berhasil. Oleh karena itu majelis hakim mengabulkan permohonan cerai penggugat dengan alasan bahwa perkawinan antara penggugat dan tergugat tidak dapat dipertahankan karena sudah tidak bisa hidup rukun sebagaimana layaknya suami-istri yang diharapkan sesuai dengan tujuan perkawinan.

Berdasarkan pertimbangan hakim dalam menetapkan hak pemeliharaan dan mendidik anak kepada penggugat sebagai ayah dari anak tersebut maka dapat diketahui bahwa pertimbangan hukum yang utama yang digunakan oleh majelis hakim adalah usia yang belum dewasa, yaitu 5 tahun dan ditinggalkan oleh penggugat begitu saja. Seperti halnya putusan sebelumnya yang diteliti, tidak ada penjelasan mengenai hak berpendapat anak.

\section{Asas Penghargaan terhadap Hak berpendapat Anak sebagai Pertimbangan Hakim dalam Menetapkan Hak Pemeliharaan Anak}

Berdasarkan kelima putusan tersebut, tampak bahwa hak berpendapat anak untuk didengar belum termuat di dalam putusan. Putusan-putusan tersebut tidak memuat pertimbangan hukum mengenai hak berpendapat anak, padahal 
ada anak yang berusia 14, 10 dan 9 tahun, usia di mana anak sudah dapat diajak berkomunikasi. Apabila keterangan hakim yang diwawancarai adalah benar menyatakan bahwa anak-anak yang sudah bisa diajak berkomunikasi akan didengar pendapatnya, maka proses ini seharusnya juga dituangkan ke dalam putusan di bagian pertimbangan hukumnya- terlepas proses ini dilakukan di luar ruang persidangan atau dalam ruang khusus untuk anak. Pemuatan ini sangat penting karena tidak hanya untuk memberikan kepastian hukum, tetapi merupakan penghargaan terhadap hak berpendapat anak yang diamanatkan oleh Konvensi Hak Anak dan Undang-Undang Perlindungan Anak.

Selanjutnya, pertimbangan hukum yang sering digunakan oleh majelis hakim dalam menentukan hak asuh anak adalah kedekatan hubungan dengan salah satu orangtuanya. Kedekatan hubungan ini meliputi kedekatan fisik dan psikologis/emosional, misalnya anak-anak telah tinggal bersama dengan salah satu orangtua untuk masa tertentu; anak-anak mendapatkan perhatian, perawatan, pemeliharaan dan pendidikan dari salah satu orangtua di mana mereka telah tinggal bersama dalam kurun waktu tertentu tersebut. Ketidakhadiran salah satu orangtua dalam memberikan perhatian, perawatan, pemeliharaan dan pendidikan menjadi faktor pertimbangan bagi hakim untuk menolak permohonan salah satu orang tua untuk mendapatkan hak asuh. Berdasarkan pertimbangan tersebut, maka hak asuh anak ini dapat diberikan kepada si ayah atau si ibu. Melalui faktor kedekatan ini majelis hakim dapat menilai tanggungjawab dari salah satu oangtua untuk keberlangsungan hidup si anak, tetapi hal ini tidak berarti meniadakan tanggungjawab salah satu orangtua yang tidak mendapatkan hak asuh. Tanggungjawab yang diatur oleh Pasal 41 UUPerkawinan tetap melekat kepada mereka hingga anak dewasa.

Pertimbangan-pertimbangan tersebut, khususnya kedekatan anak dengan salah satu orangtuanya menunjukkan bahwa majelis hakim telah memperhatikan kepentingan anak dan tumbuh kembang anak berdasarkan sudut pandang hakim dan salah satu orangtua sebagai orang dewasa tanpa melibatkan pendapat anak. Pertimbangan dan putusan yang dibuat oleh hakim telah didasarkan atas berbagai aspek seperti perkembangan fisik, mental, moral dan pendidikan anak-anak tersebut. Akan tetapi, untuk kasus yang terkait dengan terjadinya kekerasan dalam rumah tangga, tampaknya hakim belum melihat hal tersebut sebagai pertimbangan hukumnya. Pertimbangan hakim dalam kasus putusan nomor: 38/Pdt.G/2015/PN.Smg menunjukkan 
bahwa permasalahan kekerasan dalam rumah tangga belum dipandang sebagai hal yang serius sehingga belum digunakan sebagai dasar pertimbangan yang kuat utnuk menentukan apakah seseorang yang memiliki riwayat melakukan kekerasan dalam rumah tangga berhak mendapatkan hak asuh atas anak. Apabila hakim memahami permasalahan ini maka hakim tidak akan memutuskan untuk menyerahkan hak pemeliharaan anak kepada salah satu orangtua yang memiliki sejarah sebagai pelaku kekerasan dalam rumah tangga. Mengenai hal ini telah diatur di dalam Pasal 9 (3) UU Perlindungan Anak yang mengatur hak anak yang terpisahkan dari salah satu atau kedua orangtuanya untuk tetap membina hubungan yang bersifat personal dan kontak langsung dengan kedua orangtuanya secara teratur, kecuali jika hal tersebut bertentangan dengan kepentingan terbaik anak (misalnya karena adanya kekerasan dalam rumah tangga yang dilakukan oleh salah satu orangtuanya).

Jika dibandingkan dengan putusan pengadilan di berbagai negara, riwayat salah satu orangtua yang melakukan kekerasan dalam rumah tangga selalu digunakan sebagai pertimbangan untuk tidak memberikan hak asuh. Dasar yang digunakan adalah asas kepentingan yang terbaik anak, di mana pemerintah melalui hakim berusaha menjamin dan melindungi hak anak-anak agar anak tidak terkena dampak kekerasan dalam rumah tangga. Oleh karena itu sebelum hakim membuat putusan maka hakim akan selalu mendengarkan pendapat anak. Apabila ditemukan fakta adanya kekerasan dalam rumah tangga maka hakim akan memerintahkan hak untuk berkunjung secara terbatas dari salah satu orangtua yang melakukan kekerasan tersebut. Berdasarkan uraian tersebut maka tampak bahwa kepentingan yang terbaik bagi anak pada akhirnya meliputi perlindungan dari berbagai tindak kekerasan baik yang bersifat fisik, psikologis, seksual, penelantaran dan berbagai bentuk kekerasan dalam keluarga lainnya. ${ }^{15}$

Asas penghargaan terhadap hak berpendapat anak tampaknya juga belum dilaksanakan oleh lembaga peradilan, khususnya oleh para hakim di Indonesia. Hak berpendapat ini merupakan hak untuk menyampaikan pendapat atas segala sesuatu yang ada di dalam pikiran seorang anak dengan tetap mem-

\footnotetext{
15Zoe Rathus, "Shifting the Gaze: Will Past Violence be Silenced by A Further Shift of the Gaze to the Future under the New Family System?," Australian Journal of Family Law 21 (n.d.): 98; lihat juga: Taylor, "What Do We Know about Involving Children..."
} 
perhatikan privasi anak-anak tersebut.16 Mengingat bahwa hal-hal yang akan disampaikan sangat berkaitan dengan kehidupan pribadinya maka dapat dipahami jika ada keengganan untuk menyampaikannya di wilayah publik (termasuk di ruang pengadilan). Akan tetapi mengingat bahwa menentukan hak pemeliharaan dan mendidik anak sangat berkaitan erat dengan masa depan anak-anak tersebut maka selayaknya anak-anak tetap didengar pendapatnya dengan tetap melindungi privasi mereka. ${ }^{17}$ Hal ini sesuai dengan Pasal 14 (2) Konvensi Hak Anak yang menyatakan bahwa dalam pelaksanaan kebebasan berpendapat maka orangtua dan aparat penegak hukum memiliki kewajiban untuk menjamin terpenuhinya hak tersebut berdasarkan kemampuan dari anak-anak.

Penerapan asas penghargaan terhadap hak berpendapat anak di pengadilan telah dilakukan oleh banyak negara di Amerika Serikat, Swedia, Australia, dan negara-negara Eropa lainnya. ${ }^{18}$ Di beberapa negara tersebut, misalnya Amerika Serikat dan Swedia, pendapat anak-anak juga sering dikesampingkan jika tidak sesuai dengan preferensi hakim; akan tetapi pendapat anak-anak tersebut tidaklah serta merta dikesampingkan karena dalam hal-hal tertentu akan digunakan untuk memperkuat putusan hakim:

“... in both countries, young children's opinions will not be given as the sole reason for deciding a case in a particular way, however referencing a young child's preference seems to be used to add strength to what a judge has already decided..."19

Apabila praktek mendengarkan hak berpendapat anak telah dilakukan di Indonesia maka sebaiknya hal tersebut dimuat di dalam pertimbangan hukum-

${ }^{16} \mathrm{E}$. Brems, "Article 14: The Right to Freedom of Thought, Conscience and Religion," dalam A Commentary on the United Nations Convention on the Rights of the Child (Leiden: Martinus Nijhoff Publishers, 2006).

${ }^{17}$ Brems.

18Diane Pranzo, “Children's Rights and Children's Voices in Contested Custody and Visitation Cases in Sweden and the US," Childhood 20, no. 2 (2012): 283-288; Michelle Fernando, "Family Law Proceedings And The Child's Right To Be Heard In Australia, The United Kingdom, New Zealand, And Canada," Family Court Review 52, no. 1 (2014): 46-59; Linda Kelly Hill, "The Right to be Heard: Voicing the Due Process Right to Counsel for Unaccompanied Alien Children," Boston College Third World Law Journal 31, no. 1 (2011), https://lawdigitalcommons.bc.edu/twlj/vol31/iss1/3; Aoife Daly, "The right of children to be heard in civil proceedings and the emerging law of the European Court of Human Rights," The International Journal of Human Rights 15, no. 3 (2011): 441-61, https://doi.org/10.1080/ 13642980903542710.

19Pranzo, "Children's Rights and Children's Voices...," 287. 
nya. Menurut peneliti hal tersebut tidak bertentangan dengan peraturan yang ada karena permohonan hak pemeliharaan dan mendidik anak ini menjadi satu dengan permohonan untuk putusnya perkawinan. Oleh karena itu merupakan hak bagi seorang anak untuk didengar pendapatnya oleh hakim sebelum hakim membuat keputusan untuk menentukan hak asuh anak tersebut karena mendengarkan pendapat anak pada hakikatnya merupakan sebuah penghormatan atas hak-hak anak untuk berpartisipasi dan menyatakan pendapatnya dalam pengambilan keputusan terutama jika menyangkut hal-hal yang mempengaruhi kehidupannya.

Melalui wawancara dengan hakim PN Semarang diperoleh keterangan bahwa dalam hal anak sudah bisa diajak berbicara maka hakim akan menanyakan kepada anak tentang pendapatnya untuk ikut ayah atau ibunya. Pertanyaan yang diajukan bisanya dilakukan di luar ruang persidangan dan dengan menanggalkan baju hakim. ${ }^{20}$ Apabila benar demikian bahwa anak telah didengarkan hak berpendapatnya maka proses mendengarkan hak-hak anak sebagai bagian dari proses persidangan meskipun dilakukan diluar ruang persidangan tetap harus dimuat di dalam pertimbangan hukum putusan tersebut karena hal tersebut merupakan prinsip dasar asas penghargaan terhadap pendapat anak dan sebuah penghormatan atas hak-hak anak untuk berpartisipasi dan menyatakan pendapatnya dalam pengambilan keputusan terutama jika menyangkut hal-hal yang mempengaruhi kehidupannya.

Ketentuan Pasal 10 UUPA tampaknya belum terlaksana dengan baik di ranah persidangan dalam perkara perceraian yang didalamnya terdapat permohonan hak pemeliharaan dan pendidikan anak. Hal ini mengakibatkan anak hanya didengar pendapatnya di luar persidangan. Akibat hukumnya pendapat anak tersebut hanya dianggap sebagai pemberi informasi kepada majelis hakim tanpa berpengaruh dalam persidangan dan putusan pengadilan, walaupun pendapatnya tersebut mengenai diri mereka dan masa depan mereka karena yang tahu persis apa yang dibutuhkannya adalah anak itu sendiri. Hak berpendapat anak dan hak anak untuk didengar belum menjadi

${ }^{20}$ Wawancara dengan Ibu Hakim Eny Indriyani, SH, Selasa 7 Juni 2016, jam 10.30-12.00. 
pertimbangan hukum bagi hakim di dalam memberi putusan dan untuk dituangkannya ke dalam putusan..$^{21}$

Keterangan atau kesaksian anak di berbagai putusan pengadilan di luar negeri telah menjadi bagian dari putusan pengadilan. Pemuatan keterangan anak ke dalam putusan pengadilan merupakan akibat adanya asas penghargaan terhadap hak berpendapat anak. ${ }^{22}$ Hal ini seyogianya ditiru oleh lembaga peradilan di Indonesia dengan mendasarkan pada ketentuan Pasal 10 UU. No. 23 Tahun 2002 tentang Perlindungan Anak dan UU Nomor 35 Tahun 2014 tentang Perubahan atas UU Nomor 23 Tahun 2002 tentang Perlindungan Anak yang menyatakan bahwa "setiap anak berhak menyatakan dan didengar pendapatnya, menerima, mencari dan memberikan informasi sesuai dengan tingkat kecerdasan dan usianya demi pengembangan dirinya sesuai dengan nilai-nilai kesusilaan dan kepatutan".

Pasal 10 UUPA sudah sangat jelas mengatur hak berpendapat anak yang harus didengar, dan memberi kesempatan pada anak untuk mencari, menerima dan memberikan informasi yang disesuaikan dengan tingkat kecerdasan dan usianya dengan mempertimbangkan bahwa hal ini semata-mata digunakan untuk kepentingan pengembangan dirinya. Oleh karena itu, ketika anak didengar pendapatnya di dalam proses persidangan, seharusnya majelis hakim menerima dan menimbang serta menilai, bahwa pendapat anak ini dapat dijadikan pertimbangan dalam menentukan penetapan hak pemeliharaan sesuai dengan keinginannya. Penetapan oleh hakim seharusnya bukan semata-mata dibuat dengan mendasarkan pada fakta-fakta yang didengar dan dilihat di dalam persidangan yang notabene tidak pernah melibatkan anak; di mana anak sebenarnya bisa menyampaikan keinginan-keinginan dan pendapatnya sehingga anak memang mempunyai kesempatan ikut menentukan apa yang terbaik untuk dirinya.

${ }^{21}$ Sandra Keen McGlothlin, "No More 'Rag Dolls in the Corner': A Proposal to Give Children in Custody Disputes a Voice, Respect, Dignity, and Hope," Journal of Law \& Family Studies 11 (2008): 6795, http://www.cdc.gov/nchs/data/series/sr_21/sr21_046.pdf.

${ }^{22}$ Pranzo, "Children's Rights and Children's Voices..."; Fernando, "Family Law Proceedings and The Child's Right..."; Hill, "The Right to be Heard..." 


\section{Faktor-faktor Penghambat Penerapan Hak Berpendapat Anak di Persidangan dan Putusan Pengadilan}

Faktor yang menghambat penyampaian hak berpendapat anak di persidangan dan termuatnya pendapat atau keterangan anak di dalam putusan karena faktor tugas hakim yang terikat pada ketentuan beracara di Pengadilan Negeri dan keengganan hakim untuk melibatkan anak sejak awal.

Pertama, pada prinsipnya tugas hakim adalah untuk menelisik dan menyelidiki apakah ada suatu hubungan hukum yang dapat menjadi dasar sebuah gugatan itu tidak ada atau benar-benar ada. Dengan adanya hubungan hukum antara bukti dan gugatan maka gugatan penggugat bisa dikabulkan. Akan tetapi tidak semua dalil harus dibuktikan karena untuk dalil-dalil yang sudah diakui kebenarannya tidak perlu dibuktikan lagi. Pasal 1865 KUH Perdata menjelaskan bahwa: "Barang siapa mengajukan peristiwa-peristiwa atas nama dia mendasarkan suatu hak, diwajibkan membuktikan peristiwaperistiwa itu; sebaliknya barang siapa mengajukan peristiwa-peristiwa guna membantah hak orang lain, diwajibkan juga membuktikan peristiwa-peristiwa itu". Maka jelaslah, bahwa di dalam pembuktian itu jika penggugat mendalilkan sesuatu yang berkenaan dengan peristiwa tertentu, maka ia harus membuktikannya demikian sebaliknya bagi tergugat.

Namun demikian, walaupun peristiwa yang disengketakan itu telah dibuktikan, pembuktian itupun masih harus dinilai oleh hakim. Dalam memberikan penilaian ini hakim dapat bertindak bebas, yaitu hakim bisa mempercayai atau tidak. Lalu dimanakah letak pendapat anak dalam memberikan keterangan atau kesaksiannya kepada majelis hakim? Jika dilihat dari pengertian kesaksian sendiri, yaitu merupakan sebuah kepastian yang diberikan pada hakim di dalam persidangan terhadap peristiwa yang disengketakan dengan cara pemberitahuan secara lisan dan pribadi oleh orang yang bukan salah satu pihak dalam perkara, yang dipanggil dalam persidangan. Dengan demikian dapat ditegaskan, bahwa keterangan yang diberikan oleh orang saksi haruslah kejadian yang telah ia alami sendiri sebagaimana diatur dalam Pasal 1895 KUH Perdata yang menyatakan, bahwa pembuktian dengan saksi-saksi diperkenankan dalam segala hal yang tidak dikecualikan oleh undang-undang.

Kebebasan pemberian alat bukti saksi ini pun ada perkecualiannya, yaitu saksi yang dapat diperkenankan adalah saksi yang memenuhi syarat-syarat 
yang sesuai dengan Pasal 1909 dan 1912 KHUPerdata, Pasal 145 HIR dan Pasal 172 RBG. Menurut pasal-pasal tersebut orang yang tidak cakap menjadi saksi adalah: keluarga sedarah dan semenda dari salah satu pihak menurut garis lurus, suami atau istri dari salah satu pihak meskipun sudah bercerai, anak yang belum berumur 15 (lima belas) tahun dan orang gila meskipun terkadang terang ingatannya, dan orang yang selama proses perkara sidang berlangsung dimasukkan dalam tahanan atas perintah hakim (Pasal 1912 KUH Perdata).

Terhadap pasal-pasal tersebut terdapat pengecualian (yang diatur di dalam Pasal 145 ayat (2) HIR, Pasal 172 RBG ayat (2) dan Pasal 1910 KUH Perdata) yang menyebutkan bahwa: “... akan tetapi kaum sedarah dan keluarga semenda tidak dapat ditolak sebagai saksi dalam perkara perselisihan kedua belah tentang keadaan menurut hukum perdata atau tentang sesuatu perjanjian pekerjaan". Pasal 145 ayat (2) HIR juga mengecualikan Anak-anak yang belum cukup 15 (lima belas) tahun, orang gila walaupun kadang-kadang ingatannya terang mereka dalam perkara tertentu, yaitu keluarga, sehingga mereka boleh didengar keterangannya sebagai penjelasan dan untuk memberikan keterangan tersebut mereka tidak perlu disumpah.

Pasal 172 ayat (2) RBG lebih lanjut menyatakan bahwa “... keluarga sedarah atau karena perkawinan dalam sengketa mengenai kedudukan para pihak atau mengenai suatu perjanjian kerja berwenang untuk menjadi saksi”. Kemudian Pasal 1910 juga mengatur bahwa ".. namun demikian anggota keluarga sedarah dan semenda cakap untuk menjadi saksi", dalam hal: perkara mengenai kedudukan keperdataan salah satu pihak, perkara mengenai nafkah yang harus dibayar, termasuk biaya pemeliharaan dan pendidikan seorang anak yang belum dewasa, dalam suatu pemeriksaan mengenai alasan-alasan yang dapat menyebabkan pembebasan atau pemecatan dari kekuasaan orang tua atau perwalian, dan dalam perkara mengenai suatu perjanjian kerja.

Berdasarkan ketentuan-ketentuan tersebut terlihat anak yang belum berumur 15 tahun dapat menjadi saksi yang disampaikan di dalam sidang pengadilan. Ketentuan-ketentuan tersebut merupakan dasar hukum bagi hakim untuk mendengarkan pendapat anak sebagai dasar dalam pengambilan keputusan hakim untuk menentukan hak pemeliharaan anak dengan melihat pada kepentingan yang terbaik bagi anak. Akan tetapi yang sering terjadi hakim 
meminta keterangan pada anak yang belum berumur 15 (lima belas) tahun di luar sidang, sehingga keterangan yang disampaikan oleh anak jelas tidak bisa digunakan sebagai keterangan sah yang bisa menerangkan alat bukti lain yang pembuktiannya dilakukan di ruang persidangan sehingga bukti tersebut menjadi jelas. Hal ini tentunya merugikan si anak karena yang diungkapkan untuk kepentingan dirinya tidak bisa digunakan sebagai penjelasan alat bukti yang ada dan akhirnya tidak bisa dipakai sebagai pertimbangan hukum hakim di dalam membuat keputusannya.

Kedua, faktor keengganan hakim untuk melibatkan anak di dalam proses persidangan sejak awal. Dalam suatu penelitian yang terkait dengan penetapan hak pemeliharaan anak, Hakim di Pengadilan Negeri ternyata enggan untuk mendengarkan kesaksian anak. Hakim yang diwawancarai menegaskan bahwa untuk saksi dalam kasus perceraian sedapat mungkin bukan dari anak-anak pihak yang bercerai, karena akan mengganggu kondisi psikologis dari anakanak tersebut. ${ }^{23}$ Hakim akan meminta untuk diberikan saksi lain, misalnya tetangga atau saudaranya. ${ }^{24}$ Permintaan hakim terhadap saksi selain anak-anak sebenarnya tidak sesuai dengan isi dari Pasal 10 Undang-Undang Perlindungan Anak yang menyebutkan "Setiap anak berhak menyatakan dan didengar pendapatnya, menerima, mencari, dan memberikan informasi sesuai dengan tingkat kecerdasan dan usianya demi pengembangan dirinya sesuai dengan nilai-nilai kesusilaan dan kepatutan".

Berdasarkan hasil penelitian tersebut terlihat bahwa hak anak untuk didengarkan pendapatnya dan dijadikan sebagai pertimbangan hukum di dalam putusan pengadilan akan bergantung pada kemauan dan kepedulian hakim terhadap hak-hak anak dan kepentingan terbaik anak. Hakim sebenarnya dapat melakukan diskresi atas ketentuan-ketentuan tersebut sehingga alat bukti yang disampaikan dan diberikan di depan sidang pengadilan bisa dikesampingkan ketika kasusnya berkaitan dengan keterangan atau hak berpendapat anak.

\footnotetext{
${ }^{23}$ Ivan Ricardo Gitowardojo, "Pemenuhan Hak Anak untuk Bertemu dengan Salah Satu Orang Tuanya yang tidak Mendapatkan Hak Asuh setelah Terjadinya Perceraian menurut Pasal 14 Ayat (2) Undang-Undang Nomor 35 Tahun 2014 tentang Perubahan Atas Undang-Undang Nomor 23 Tahun 2002 tentang Perlindungan Anak (Studi Kasus Putusan No.30/Pdt.G/2016/Pn.Smg dan Putusan No.45/Pdt.G/2016/Pn.Smg)" (Tesis, Fakultas Hukum dan Komunikasi, Unika Soegijapranata, 2017), 34.

${ }^{24}$ Gitowardojo, 44.
} 
Hasil penelitian tersebut semakin memperkuat hasil penelitian yang dilakukan oleh penulis ketika tidak ada anak-anak yang didengar pendapatnya meskipun ada anak-anak yang usianya sudah dapat diajak berkomunikasi (misalnya berumur 14, 10 dan 8 tahun) dan memenuhi ketentuan peraturan perundang-undangan yang berkaitan dengan proses beracara di pengadilan sebagaimana telah disebut dan dibahas di atas

Keengganan hakim untuk mendengarkan pendapat anak secara tidak langsung menunjukkan pola pikir dan pola hubungan orang dewasa terhadap anak yang masih didominasi konsep dan nilai patriarkhi yang menganggap anak adalah properti. ${ }^{25}$ Apabila alasan yang dikemukakan adalah faktor psikologis sebagaimana yang dikemukakan oleh hakim dalam penelitian terdahulu, maka hakim dapat meminta tenaga ahli psikolog atau pekerja sosial untuk mendampingi anak yang hendak dimintai keterangannya. Pendampingan psikolog atau pekerja sosial terhadap anak-anak yang berhadapan dengan hukum pada hakikatnya merupakan suatu kewajiban bagi pemerintah untuk menjamin dan melindungi terpenuhinya hak-hak anak di Indonesia. Penggunaan dan pendampingan para tenaga ahli kepada anak-anak dalam proses persidangan baik di perkara pidana maupun perdata diperlukan karena para hakim yang berpengalaman pun terkadang tidak dapat menemukan 'bukti' karena terbatasnya pengetahuan hakim. ${ }^{26}$ Selain itu kasus yang dihadapi hakim yang sangat beragam dan multi dimensi seyogianya diproses dan diselesaikan melalui pendekatan dari berbagai aspek secara multi dimensi juga. Woodhouse menyatakan pentingnya menggunakan berbagai pendekatan dalam membuat putusan yang berkaitan dengan kepentingan anak-anak:

“... decision-making for children is an inherently multidisciplinary enterprise. They adopt an interdisciplinary framework and pursue the daunting task of melding legal and psychological aspects into a cohesive whole. In this collaborative each group seems to treat the other with respect. Lawyers defer

${ }^{25}$ Barbara Bennett Woodhouse, “'Out of Children's Needs, Children's Rights': The Child's Voice in Defining the Family," Brigham Young University Journal of Public Law 8, no. 2 (1994): 321-41, https://digitalcommons.law.byu.edu/jpl/vol8/iss2/4.

26Vicki Banham et al., "Acknowledging Children's Voice and Participation in Family Courts: Criteria that Guide Western Australian Court Consultants," Social Inclusion 5, no. 3 (2017): 155-163; Samantha Jeffries, "In the Best Interests of the Abuser: Coercive Control, Child Custody Proceedings and the 'Expert' Assessments That Guide Judicial Determinations," Laws 5, no. 1 (2016): 14, https://doi.org/10.3390/laws5010014. 
to psychologists on issues such as how to interpret a custody evaluation, and social scientists defer to legal scholars on issues such as the social and systemic importance of protecting individual rights in the adjudication process. The melding of these perspectives is a crucial step toward constructing a more just decision-making process for children and families..." ${ }^{27}$

Mengingat bahwa hak berpendapat anak ini merupakan hak yang wajib dipenuhi dan dilindungi oleh negara melalui aparat penegak hukum karena sangat jelas diatur di dalam UU No. 23 Tahun 2002 dan UU No 35 Tahun 2014 tentang Perubahan UU Nomor 23 Tahun 2002 tentang Perlindungan Anak maka sudah sepantasnya apabila semua peraturan perundang-undangan yang berlaku sebelum dikeluarkannya UUPA diperbaharui dan disesuaikan dengan nilai-nilai dan asas-asas dalam UUPA.

Uraian di atas menunjukkan bahwa faktor yang menghambat dalam melaksanakan hak berpendapat anak dalam persidangan tentang perkara hak pemeliharaan dan pendidikan anak justru ada pada pemahaman hakim terhadap hak berpendapat anak dan keberanian hakim untuk memuat pendapat anak dalam pertimbangan hukum di dalam putusannya. Hakim seyogianya berani melakukan terobosan hukum terhadap ketentuan-ketentuan hukum yang berlaku yang kurang berpihak pada pemenuhan hak-hak anak. Terobosan hukum yang dilakukan oleh hakim berdasarkan keyakinannya sangat diperlukan sehingga hak anak untuk berpendapat benar-benar dapat terpenuhi dan terlindungi.

\section{E. Kesimpulan}

Berdasarkan putusan yang diteliti, ada tiga pertimbangan hukum yang digunakan hakim dalam menetapkan hak pemeliharaan dan mendidik anak, yaitu: keterangan saksi, usia anak yang belum dewasa dan kedekatan hubungan antara anak dengan salah satu orangtua. Keputusan yang dibuat hakim lebih banyak dipengaruhi pada perspektif hakim dalam menafsirkan 'kepentingan' anak daripada perspektif anak yang menjadi perebutan hak pemeliharaannya oleh kedua orangtuanya yang bercerai. Hal ini bisa diketahui karena perspektif

${ }^{27}$ Barbara Bennett Woodhouse, “Talking about Children's Rights in Judicial Custody and Visitation Decision-Making," Family Law Quarterly36, no. 1 (2002): 105-33, https://doi.org/10.2307/25740371. 
hak anak tidak terlihat di dalam pertimbangan-pertimbangan yang dibuat oleh hakim melalui putusannya. Berdasarkan kelima putusan tersebut, tampak bahwa hak berpendapat anak untuk didengar belum termuat di dalam putusan

Faktor yang menjadi hambatan dalam penyampaian pendapat anak di persidangan menurut hakim yang diwawancarai karena menghindari tekanan psikologis pada anak. Selain itu karena ketaatan hakim terhadap asas-asas di pengadilan sehingga tidak menerapkan pasal-pasal yang bersifat pengecualian dan ketentuan peraturan perundangan yang bersifat khusus. Mengingat bahwa hak berpendapat anak belum sepenuhnya diperhatikan maka proses untuk mendengar dan mendapat penjelasan pendapat anak yang dilakukan di luar persidangan maupun di dalam persidangan harus difasilitasi melalui sistem dan prosedur yang khusus untuk itu. Oleh karena itu perlu dibentuk sistem dan prosedur untuk mengakomodasi kebutuhan hak berpendapat anak di dalam proses peradilan, khususnya hak berpendapat anak yang dimasukkan ke dalam pertimbangan hukum ketika hakim membuat putusan dengan pertimbangan hal tersebut dianggap merupakan bagian dari proses persidangan dengan pokok perkara yang menjadi bagian dari perkara perceraian yang dimintakan oleh para pihak sebagai penggugat dan tergugat.[s]

\section{Daftar Pustaka}

Badali, Michele Peterson, Rona Abramovitch, dan Juliane Duda. 'Young Children's Legal Knowledge and Reasoning Ability." Canadian Journal of Criminology 39, no. 2 (1997): 145-170.

Banham, Vicki, Alfred Allan, Jennifer Bergman, dan Jasmin Jau. “Acknowledging Children's Voice and Participation in Family Courts: Criteria that Guide Western Australian Court Consultants." Social Inclusion 5, no. 3 (2017): 155163.

Brems, E. "Article 14: The Right to Freedom of Thought, Conscience and Religion." Dalam A Commentary on the United Nations Convention on the Rights of the Child. Leiden: Martinus Nijhoff Publishers, 2006.

Daly, Aoife. "The right of children to be heard in civil proceedings and the emerging law of the European Court of Human Rights." The International 
Journal of Human Rights 15, no. 3 (2011): 441-61. https://doi.org/10.1080/ 13642980903542710.

Douglas, Gillian, dan Mervyn Murch. “Taking Account of Children's Need in Divorce: A Study of Family Solicitors 's Responses to New Policy and Practice Initiatives." Child and Family Law Quarterly 14, no. 1 (2002): 57-75.

Fernando, Michelle. "Family Law Proceedings And The Child's Right To Be Heard In Australia, The United Kingdom, New Zealand, And Canada." Family Court Review 52, no. 1 (2014): 46-59.

Fitzgerald, Robyn. "How Are Children Heard in Family Law Proceeding in Australia?" Southern Cross University Law Review 6 (2002): 177-203.

Flowerdew, Jennifer, dan Bren Neale. "Trying to Stay Apace: Children with Multiple Challenges in Their Post-Divvorce Family Lives." Childhood Journal 10, no. 2 (2003): 148.

Gitowardojo, Ivan Ricardo. Pemenuhan Hak Anak untuk Bertemu dengan Salah Satu Orang Tuanya yang tidak Mendapatkan Hak Asuh setelah Terjadinya Perceraian menurut Pasal 14 Ayat (2) Undang-Undang Nomor 35 Tahun 2014 tentang Perubahan Atas Undang-Undang Nomor 23 Tahun 2002 tentang Perlindungan Anak (Studi Kasus Putusan No.30/Pdt.G/2016/ Pn.Smg dan Putusan No.45/Pdt.G/2016/Pn.Smg)" Tesis. Fakultas Hukum dan Komunikasi, Unika Soegijapranata, 2017.

Hill, Linda Kelly. "The Right to be Heard: Voicing the Due Process Right to Counsel for Unaccompanied Alien Children." Boston College Third World Law Journal 31, no. 1 (2011). https://lawdigitalcommons.bc.edu/twlj/vol31/iss1/3.

Jeffries, Samantha. "In the Best Interests of the Abuser: Coercive Control, Child Custody Proceedings and the 'Expert' Assessments That Guide Judicial Determinations." Laws 5, no. 1 (2016): 14. https://doi.org/10.3390/ laws5010014.

Maunsel, Catherine. "What Do They Know about the Legal System? Intreviews with Irish Children." Dalam Researching Children's Experiences: Qualitative Approaches, diedit oleh Diane Hogan dan Robbie Gilligan, 35-49. Dublin: The Children's Research Centre, 1998.

McGlothlin, Sandra Keen. "No More 'Rag Dolls in the Corner': A Proposal to Give Children in Custody Disputes a Voice, Respect, Dignity, and Hope." Journal of Law \& Family Studies 11 (2008): 67-95. http://www.cdc.gov/nchs/ data/series/sr_21/sr21_046.pdf. 
Pranzo, Diane. “Children's Rights and Children's Voices in Contested Custody and Visitation Cases in Sweden and the US." Childhood 20, no. 2 (2012): 283288.

Rathus, Zoe. "Shifting the Gaze: Will Past Violence be Silenced by a Further Shift of the Gaze to the Future under the New Family System?" Australian Journal of Family Law 21 (n.d.): 98.

Smart, Carol. "Introduction: New Perspectives on Childhood and Divorce." Childhood 10, no. 2 (2003): 123-29. https://doi.org/10.1177/ 0907568203010002001.

Taylor, Nicola. "What Do We Know about Involving Children and Young People in Family Law Decision Making? A Research Update." Australian Journal of Family Law 20 (2006): 154.

Woodhouse, Barbara Bennett. “'Out of Children's Needs, Children's Rights': The Child's Voice in Defining the Family." Brigham Young University Journal of Public Law 8, no. 2 (1994): 321-41. https://digitalcommons.law.byu.edu/ jpl/vol8/iss2/4.

——_. "Talking about Children's Rights in Judicial Custody and Visitation Decision-Making." Family Law Quarterly 36, no. 1 (2002): 105-33. https://doi.org/10.2307/25740371. 